\title{
Birds associated with treefall gaps in a lowland forest in southwestern Brazilian Amazonia
}

\author{
Jônatas LIMA ${ }^{1 *}$, Edson GUILHERME² \\ Universidade Federal do Acre (UFAC), Programa de Pós-Graduação em Ecologia e Manejo de Recursos Naturais, CEP 69920-900, Rio Branco, AC, Brazil \\ 2 Universidade Federal do Acre (UFAC), Centro de Ciências Biológicas e da Natureza, Laboratório de Ornitologia, CEP 69920-900, Rio Branco, AC, Brazil \\ * Corresponding author: jonatasornito@gmail.com; (D) https://orcid.org/0000-0002-9663-5208
}

\begin{abstract}
Natural communities are dynamic systems in time and space. The spatial distribution of plants and animals tends to coincide with the availability of resources needed for the survival and reproduction of each species. Natural treefall gaps offer a number of resources that influence the distribution of birds within the forest. We compared the understory bird assemblages of natural treefall gaps (15 sampling points) with those found in the adjacent forest (15 points) in the Humaitá Forest Reserve in southwestern Brazilian Amazonia. We used mist-nets to sample birds and obtained 700 captures of 105 species. Species richness, number of individuals, and species composition were all similar between gaps and forest, although six species presented some degree of association with the gaps, and nine with the forest. Nectarivores preferred gaps significantly over forest, whereas insectivores and frugivores were distributed equally between gaps and forest. Vegetation height and density differed between gaps and forest, and influenced the distribution of bird species in the two environments. Fruit availability was positively correlated with frugivore abundance in gaps. Overall, 33.3\% of the birds associated with the treefall gaps are from lower forest canopy, while the others are understory species. We showed that the use of natural gaps by birds in a fragmented landscape of the Amazon forest contributes to the environmental heterogeneity and succession dynamics following natural events of habitat disturbance.
\end{abstract}

KEYWORDS: tropical forests, Amazon region, forest fragment, understory

\section{Aves associadas a clareiras naturais em uma floresta de terras baixas no sudoeste da Amazônia brasileira}

\section{RESUMO}

As comunidades naturais são sistemas dinâmicos no tempo e no espaço. A distribuição espacial de plantas e animais coincide com a disponibilidade dos recursos necessários para a sobrevivência e reprodução de cada espécie. Clareiras naturais oferecem vários recursos que influenciam a distribuição de aves na floresta. Comparamos a assembleia de aves de sub-bosque de clareiras naturais (15 clareiras) com a encontrada na floresta adjacente (15 pontos) na Reserva Florestal Humaitá, no sudoeste da Amazônia brasileira. Amostramos aves com redes de neblina e contabilizamos 700 capturas de 105 espécies. A riqueza de espécies, o número de indivíduos e a composição de espécies foram semelhantes entre clareiras e floresta, mas seis espécies foram mais associadas com as clareiras e nove com a floresta. Os nectarívoros preferiram significativamente clareiras à floresta, enquanto os insetívoros e frugívoros se distribuíram igualmente entre clareiras e floresta. A altura e a densidade da vegetação variaram significativamente entre clareiras e floresta e influenciaram a distribuição das espécies nos dois ambientes. A disponibilidade de frutos foi correlacionada positivamente com a abundância de frugívoros nas clareiras. Em geral, 33,3\% das aves associadas às clareiras são espécies de sub-dossel e as demais de sub-bosque. Mostramos que o uso de clareiras pelas aves em uma paisagem fragmentada da Amazônia contribui para a heterogeneidade ambiental e a dinâmica de sucessão após eventos naturais de perturbação do habitat.

PALAVRAS-CHAVE: florestas tropicais, região amazônica, fragmentos florestais, sub-bosque 


\section{INTRODUCTION}

Biological communities in natural forests are formed by a mosaic of microhabitats and their associated organisms (Whittaker and Levin 1977). Environmental variability, resource availability, and the adaptive capacity of different organisms will determine the composition of local assemblages (Townsend et al. 2010). In natural communities, species assemblages tend to be similar in environments that have similar abiotic conditions, such as climate, soil, and water (Thompson and Sorenson 2000). Species will be favored distinctly by environmental conditions, including those created in novel environments (Sousa 1984), leading to the unequal spatial distribution of natural communities (Scheiner et al. 2000). Mosaics of environments and their associated biological communities are mediated by events such as landslides (Garwood et al. 1979), wildfires (Silva et al. 2015), and natural treefall in forests, coupled with the succession process (Thompson and Sorenson 2000).

In forest ecosystems, natural treefall, including events caused by wind, creates open spaces within the forest, known as treefall gaps (Baker et al. 2016). The gaps promote ecosystem dynamics, help shape the structure of natural communities and contribute to the heterogeneity in the composition of tropical forests (Brokaw 1985; Wunderle et al. 1987; Levey 1988; Hubbell et al. 1999; Busing and Brokaw 2002; Lima 2005; Schnitzer and Carson 2010; Maranho and Salimon 2015; Terborgh 2017).

Treefall gaps have higher sunlight incidence and higher density of plants with young leaves than adjacent forest, which attracts herbivorous arthropods (Richards and Coley 2007) and are referred to as nutrient hotspots due to their high rates of decomposition and mineralization (Scharenbroch and Bockheim 2008). In forests, many organisms are adapted specifically to the spectrum of conditions and resources provided by treefall gaps, resulting in high abundance and diversity, including butterflies (Pardonnet et al. 2013), spiders (Peres et al. 2014), snails (Alvarez and Willig 1993), bats (Crome and Richards 1988), amphibians (Strojny and Hunter 2010), small mammals (Beck et al. 2004), and birds (Schemske and Brokaw 1981; Levey 1990; Wunderle et al. 2005).

Ornithological surveys of forest fragments in southwestern Amazonia have revealed a high diversity of species, many of which are rare and/or endemic, with poorly-known ecological characteristics (Guilherme 2001, 2012, 2016; Rasmussen et al. 2005; Mestre et al. 2010). Our objective was to understand the influence of treefall gaps on the distribution of birds in a southwestern Amazonian forest. Specifically, we tested the hypotheses that (i) there are more species in treefall gaps relative to adjacent continuous forest due to their heterogeneity, and species composition and abundance differ between gaps and forest; (ii) some species have an intrinsic preference for gaps or forest; (iii) the vegetation structure and food resources (flowers and fruits) influence species richness, composition, and abundance of birds, so that trophic guilds of birds differ between gaps and forest; and (iv) the bird species associated with gaps are found in other specific forest strata.

\section{MATERIAL AND METHODS}

\section{Study area}

We conducted the study in the Humaitá Forest Reserve (HFR), a 2,000-ha forest fragment administered by Universidade Federal do Acre (UFAC), in Porto Acre, Acre state, southwestern Brazilian Amazonia (9045'19"S, 67040'18"W; Figure 1). HFR is covered by open terra firme rainforest, interspersed with palm stands and patches of Guadua bamboo, as well as alluvial forest, known locally as várzea (Acre 2010; IBGE 2012). The climate is humid tropical, with mean annual temperatures of $24-26^{\circ} \mathrm{C}$ (Alvares et al. 2013), and mean annual rainfall of approximately 1,900 $\mathrm{mm}$. The rainy season extends from October to April, and the dry season from May to September (Duarte 2006). See Pedroza et al. (2020) for details on the local bird fauna.

We considered two forest habitats in the HFR (Figure 2a): natural treefall gaps and undisturbed continuous forest (henceforth gap and forest). A gap is 'a vertical opening in the forest extending through the canopy to within $2 \mathrm{~m}$ of the forest floor' (Brokaw 1982). We calculated the area of the gaps based on their maximum length and width (Wunderle et al. 2005). We defined one sampling site randomly within each gap (Figure $2 \mathrm{~b}, \mathrm{c}$ ) and a control site in the adjacent forest, located $50 \mathrm{~m}$ away from the nearest gap edge (sensu Levey

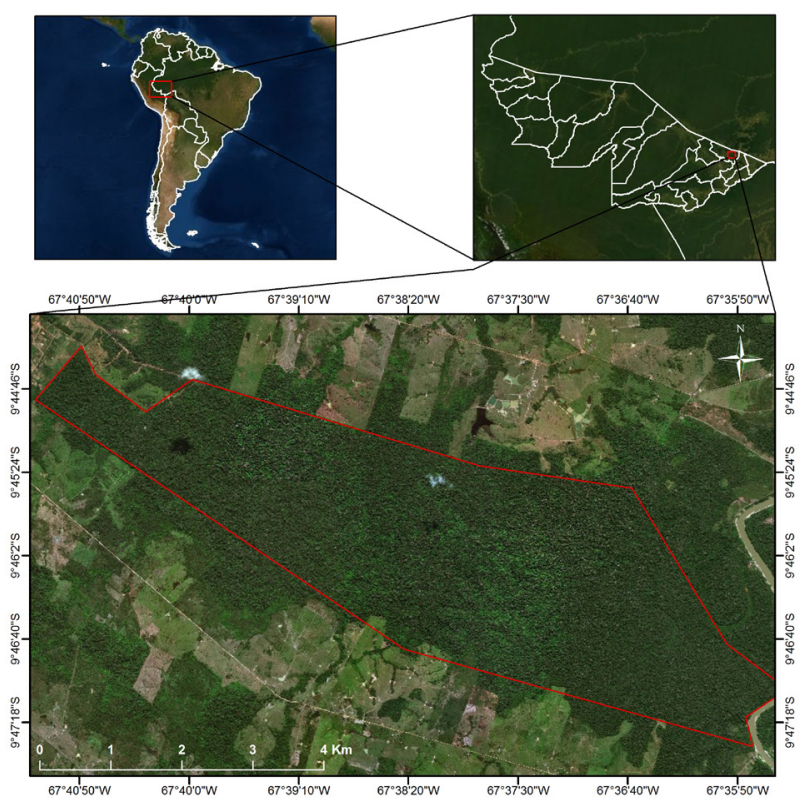

Figure 1. Location of the Humaitá Forest Reserve (outlined in red) in Brazil and in the state of Acre, municipality of Porto Acre. (@ ESRI). This figure is in color in the electronic version. 


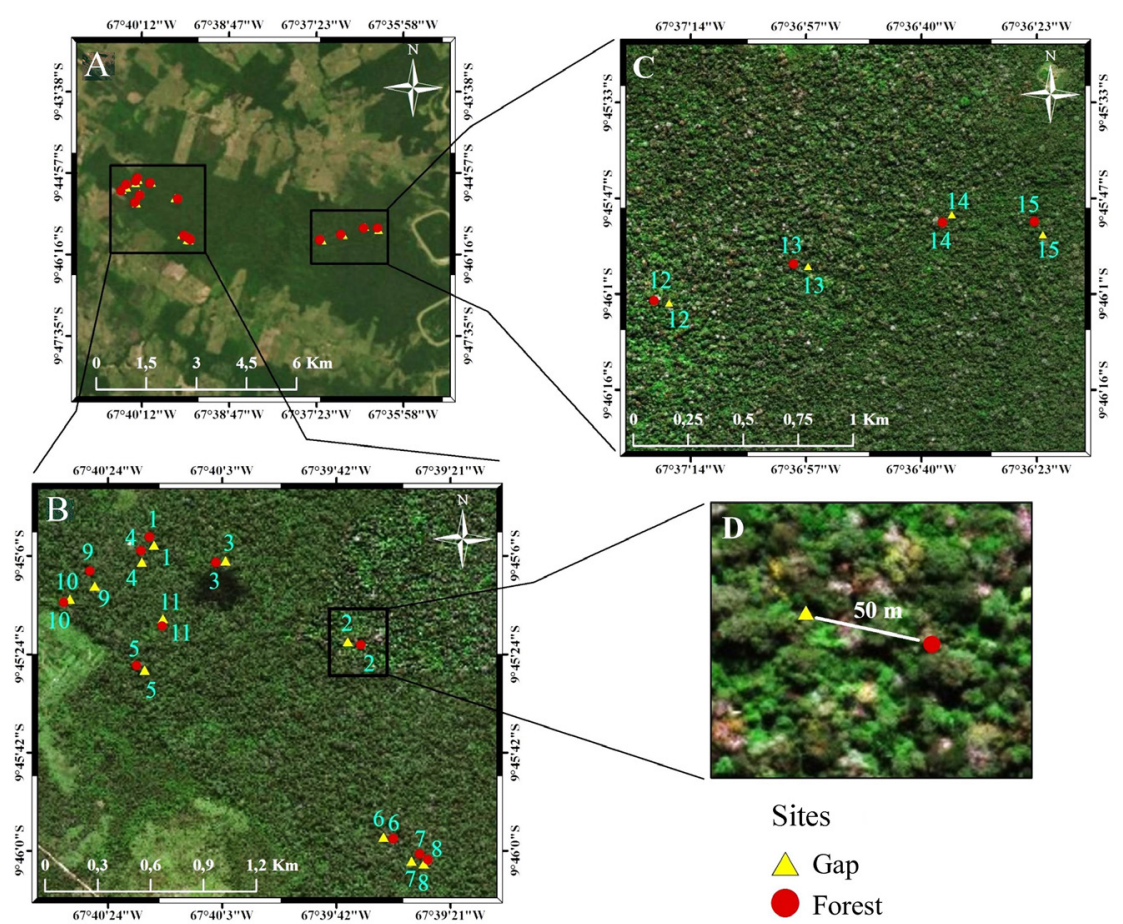

Figure 2. A - Location of the pairs of treefall gap and forest sampling sites in the Humaitá Forest Reserve (HFR); B, C - Enlarged location maps of the gap and forest sites in the western and eastern portions of the HFR; D - Detail of a pair of gap/forest site showing the distance between them (๑ ESRI). This figure is in color in the electronic version.

1988; Figure 2d). Overall we had 15 gap and 15 forest sites mapped in a GIS program (ArcMap, ESRI 2015).

We sampled birds with mist-nets $12 \times 2.5 \mathrm{~m}$ and $36-\mathrm{mm}$ mesh, from May to November 2018, between 05h30 and 17h30. At each site, we arranged two nets in either a straight line or in $\mathrm{L}$ or $\mathrm{T}$ configuration, to fit into the gap, with the same layout being used in the forest. We banded all the birds captured on one tarsus with a permanent metal ring engraved with a unique numerical code provided by the Brazilian government's Centro Nacional de Pesquisa para Conservação das Aves Silvestres (CEMAVE/ICMBio) to EG's project \# 1099, authorized by SISBIO license \# 23269-1. We sampled each pair of gap-forest sites simultaneously on two consecutive days during four field sessions of 30 days, with intervals of 20-34 days between sessions. Overall, we sampled each site on eight days. We adopted the bird species nomenclature of Gill and Donsker (2019).

We classified each species as frugivore, insectivore, nectarivore, omnivore, or piscivore (sensu Wilman et al. 2014). Regarding the forest stratum in which the species typically forages, each species captured in the gaps was classified as terrestrial, understory, mid-story, canopy or secondary-growth species, based on Henriques et al. (2003) and Schulenberg et al. (2010). Terrestrial birds forage primarily on the ground, understory birds at heights of up to $5 \mathrm{~m}$ in shrubs and small trees, mid-story birds above $5 \mathrm{~m}$ and below the canopy, and secondary-growth birds exploit regenerating habitats.
We estimated the structure of vegetation in the gap and forest sites using the method of Wunderle et al. (2005). We obtained vegetation height profiles from two parallel transects, one located on each side of the mist-net, every $1 \mathrm{~m}$ along each transect using a 3-m pole as a reference scale. We recorded the presence or absence of vegetation touching the pole within each height interval. The height intervals (in meters) were: $0-0.5,0.51-1,1.01-2,2.01-3,3.01-4,4.01-6,6.01-8$, $8.01-10,10.01-12,12.01-15,15.01-20$, and $>20$. An estimate of percentage cover was based on these data for each height interval. We evaluated the density of the vegetation for all gap and forest site using a modified version of the method of Levey (1988). We demarcated an area of $48 \mathrm{~m}^{2}$ between the transects, within which we counted the number of trunks, shrubs, branches, and stems with a diameter $\geq 7 \mathrm{~mm}$. We determined the absolute density of the plants in the plots using the formula of Freitas and Magalhães (2012). We quantified plants bearing flowers and/or fruits within the entire gap area below $10 \mathrm{~m}$ height (sensu Levey 1988). We collected a sample of each flowering or fruiting plant and we prepared exsiccates deposited and identified in the Laboratory of Botany and Plant Ecology (LABEV) at UFAC. Plant species nomenclature followed Daly and Silveira (2008) and Medeiros et al. (2014).

\section{Data analysis}

Our sampling units were 15 gaps compared to 15 forest sites. To compare species richness between gap and forest, after confirming the normality of the data (Sokal and Rohlf 1995), 
we applied a paired $t$ test. We estimated species richness in gaps and forest using the nonparametric Jackknife 1 procedure. We evaluated the difference in the number of individuals captured in gaps and forest using the Chi-square test. We ordered the species composition in the gaps and forest through non-metric multidimensional scaling (NMDS) for abundance data using Bray Curtis similarity index. We ran the NMDS ordination through the function 'metaMDS' in the vegan package (Oksanen et al. 2018) in the R environment. To test for differences in species composition between gap and forest sites we ran a global test using Permutational Multivariate Analysis of Variance (PERMANOVA) (Anderson 2001) using the function 'adonis', employing 1000 permutations.

To identify habitat specialists and associates we ran an indicator value (IndVal) method (Cáceres and Legendre 2009) through the function 'indval' in the indicspecies package. This analysis takes into account specificity and fidelity. A perfect indicator species must occur only in samples of a certain category (specificity) and also in all the category units (fidelity). We estimated the significance of this analysis with a Monte Carlo test with 10000 randomizations through the function 'multipatt'. We classified the species in two categories: (a) habitat specialists (gap or forest), based on a p value $\leq$ 0.05 ; and (b) habitat associates, as the species captured at a frequency greater than $40 \%$ in gaps or forest.

To evaluate the variation in height and density of vegetation between gaps and forest, we applied the nonparametric Wilcoxon paired test. To evaluate the association between the number of flowering or fruiting plants in the gaps and the abundance and richness of nectarivore and frugivore species, respectively, we applied the Spearman correlation coefficient $(r)$. To evaluate the influence of the vegetation structure on the composition and abundance of the bird assemblages, we used parcial redundance analysis (pRDA, see Legendre and Legendre 1998). To test if the model is significant, we ran a global test using Analysis of Variance (ANOVA), employing 1000 permutations.

To evaluate the variation in the frequency of trophic guilds between gaps and forest, and the frequency of the species present in each guild found in gaps and/or forest, we applied Chi-square tests. We calculated the percentage of use of the different foraging strata in gaps or forest by birds pooled in each specialist or associate category. We calculated the percentage of species that used specific strata, including only the species for which at least six individuals were captured in the mist-nets. We applied the paired Wilcoxon and Chi-square tests to evaluate the variation in the frequency of the different categories. We ran all analyses in the $\mathrm{R}$ software, version 3.5.1 (R Core Team 2018).

\section{RESULTS}

Total sampling effort was 3,916 h. We captured 700 birds belonging to 105 species and 26 families (Supplementary Material, Table S1). We banded 531 individuals and recaptured 144 . We captured a similar number of individuals in gaps (366) and forest (334), with no significant difference between habitats $\left(\chi^{2}=1.4, \mathrm{df}=1, \mathrm{p}=0.22\right)$. Species richness was similar between gaps and forest, 81 and 80 species, respectively $(\mathrm{t}=0.66, \mathrm{df}=14, \mathrm{p}=0.52)$. The species rarefaction curve did not present a tendency to stabilize, with an estimated total of 101 species for the gaps and 103 for the forest. The composition of the bird assemblages did not vary significantly between gaps and forest (PERMANOVA: $F=$ $1.40, \mathrm{df}=1, \mathrm{p}=0.09$, stress $=0.25$ ).

We detected an association with gaps or forest in 15 species (Table 1), corresponding to $14.2 \%$ of the 105 recorded species. We classified three (20\%) of these species as habitat specialists, two of which were specialized in gaps, and one in forest (Table 1). Four species $(26.6 \%)$ were associated with gaps and eight $(50 \%)$ with forest (Table 1$)$. The capture frequency of species with some degree of habitat association was similar between gaps and forest $\left(\chi^{2}=1.81, \mathrm{df}=1, \mathrm{p}=0.17\right)$. The recapture data (Figure 3) indicate that Thalurania furcata, Sciaphylax hemimelaena, Xenops minutus, Lepidothrix coronata, Pipra fasciicauda and Mionectes oleagineus moved either between gaps or between gap and forest (Table 2).

Table 1. Specialist and associate bird species in treefall-gap and forest sampling sites in the Humaitá Forest Reserve, southwestern Brazilian Amazonia. N captures $=$ number of individual captures. The frequency and $p$ values are derived from IndVal tests. Guilds: $I$ = insectivore; $\mathrm{F}=$ frugivore; $\mathrm{N}=$ nectarivore; $\mathrm{O}=$ omnivore. The trophic guild classification followed Wilman et al. (2014).

\begin{tabular}{|c|c|c|c|c|c|c|}
\hline \multirow{2}{*}{ Species } & \multicolumn{2}{|c|}{ N captures } & \multirow{2}{*}{$\begin{array}{c}\text { Frequency } \\
\%\end{array}$} & \multicolumn{2}{|c|}{ IndVal test } & \multirow{2}{*}{ Guild } \\
\hline & Gap & Forest & & Value & $p$ & \\
\hline \multicolumn{7}{|l|}{ Treefall gap specialists } \\
\hline Hypocnemis peruviana & 14 & 1 & 40 & 0.37 & 0.03 & । \\
\hline Oryzoborus angolensis & 12 & 2 & 60 & 0.51 & 0.01 & $\mathrm{~F}$ \\
\hline \multicolumn{7}{|l|}{ Associated with treefall gaps } \\
\hline Sittasomus griseicapillus & 8 & 4 & 40 & 0.26 & 0.41 & । \\
\hline Thamnomanes schistogynus & 10 & 4 & 40 & 0.28 & 0.30 & । \\
\hline Sciaphylax hemimelaena & 16 & 7 & 40 & 0.27 & 0.30 & । \\
\hline Pipra fasciicauda & 35 & 30 & 66 & 0.35 & 0.84 & $\mathrm{~F}$ \\
\hline \multicolumn{7}{|l|}{ Forest specialists } \\
\hline Thamnomanes ardesiacus & 0 & 7 & 40 & 0.40 & 0.01 & I \\
\hline \multicolumn{7}{|l|}{ Associated with forest } \\
\hline Sclrerurus caudacutus & 5 & 6 & 40 & 0.21 & 1.00 & । \\
\hline Dendrocincla merula & 10 & 20 & 66 & 0.44 & 0.05 & । \\
\hline Dendrocincla fuliginosa & 5 & 11 & 40 & 0.27 & 0.30 & I \\
\hline Glyphorhynchus spirurus & 3 & 9 & 40 & 0.30 & 0.18 & I \\
\hline Isleria hauxwelli & 15 & 16 & 46 & 0.24 & 0.86 & । \\
\hline Oneilornis salvini & 9 & 16 & 46 & 0.29 & 0.40 & I \\
\hline Willisornis poecilinotus & 7 & 15 & 53 & 0.36 & 0.11 & । \\
\hline Phlegopsis nigromaculata & 6 & 12 & 46 & 0.31 & 0.22 & । \\
\hline
\end{tabular}



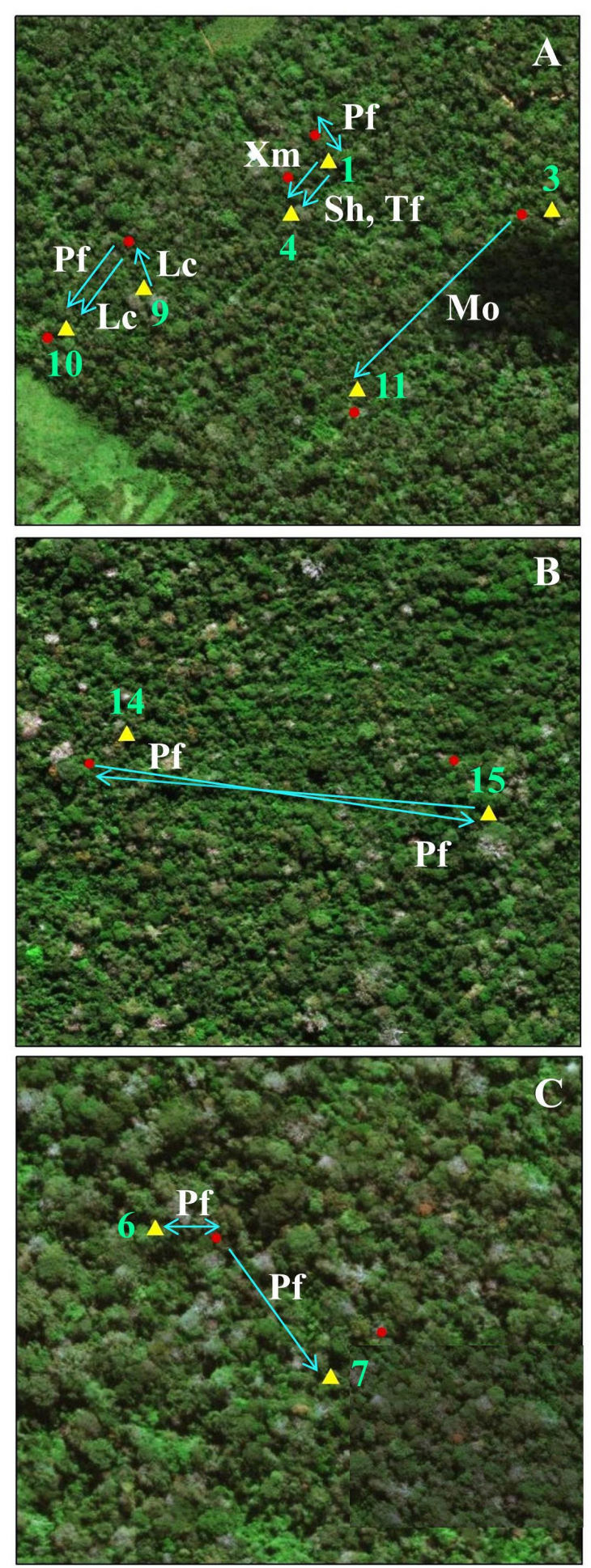

Figure 3. Movements of individuals of six bird species between gap (triangles) and forest (circles) sampling sites within the Humaitá Forest Reserve (Acre, Brazil), as indicated by recaptures. Numbers indicate the pair of gap/forest sampling sites. Species are indicated by letters: Thalurania furcata (Tf), Xenops minutus (Xm), Pipra fasciicauda (Pf), Sciaphylax hemimelaena (Sh), Lepidothrix coronata (LC) and Mionectes oleagineus (Mo). The arrows indicate the direction of the movement from the first to second capture. Double arrows indicate two recaptures at the same point (๑ ESRI). This figure is in color in the electronic version.
Table 2. Movements of recaptured individuals of six bird species between treefallgap and forest sampling sites in the Humaitá Forest Reserve, in southwestern Brazilian Amazonia, showing the distance travelled between locations. Sampling site indicates the codes of the specific sampling site (see Figure 2), where $G=$ gap and $F=$ forest. Distance $=$ linear distance traveled calculated using Google Earth Pro.

\begin{tabular}{|c|c|c|c|c|c|}
\hline \multirow[b]{2}{*}{ Species } & \multicolumn{3}{|c|}{ Sampling site } & \multirow{2}{*}{$\begin{array}{c}\text { Days } \\
\text { between } \\
\text { captures }\end{array}$} & \multirow[b]{2}{*}{$\begin{array}{c}\text { Distance } \\
(\mathrm{m})\end{array}$} \\
\hline & $\begin{array}{c}\text { 1st } \\
\text { capture }\end{array}$ & $\begin{array}{c}\text { 2nd } \\
\text { capture }\end{array}$ & $\begin{array}{c}\text { 3rd } \\
\text { capture }\end{array}$ & & \\
\hline Thalurania furcata & G1 & G4 & & 2 & 119.7 \\
\hline Xenops minutus & G1 & G4 & & 142 & 119.7 \\
\hline Sciaphylax hemimelaena & G1 & G4 & & 40 & 119.7 \\
\hline Mionectes oleagineus & F3 & G11 & & 4 & 445 \\
\hline Lepidothrix coronata & G9 & F9 & G10 & $1 / 4$ & $50 / 207.3$ \\
\hline Pipra fasciicauda & G15 & $\mathrm{F} 14$ & & 13 & 420.9 \\
\hline Pipra fasciicauda & F6 & G7 & & 171 & 172.7 \\
\hline Pipra fasciicauda & $\mathrm{F} 1$ & G1 & $\mathrm{F} 1$ & $1 / 145$ & 50 \\
\hline Pipra fasciicauda & F6 & G6 & F6 & $1 / 83$ & 50 \\
\hline Pipra fasciicauda & F9 & G10 & & 83 & 207.3 \\
\hline Pipra fasciicauda & F14 & G15 & & 19 & 660.6 \\
\hline
\end{tabular}

Nectarivores $(9 \%)$ were significantly more frequent in the gaps than in the forest $\left(\chi^{2}=4.41, \mathrm{df}=1, \mathrm{p}=0.03,33\right.$ captures in gaps and 18 in forest) (Figure 4). Most frequent nectarivores in the gaps were Glaucis hirsutus $\left(\chi^{2}=4.40, \mathrm{df}=\right.$ $1, \mathrm{p}=0.03)$ and $T$. furcata $\left(\chi^{2}=5.40, \mathrm{df}=1, \mathrm{p}=0.01\right)$. The frugivores were distributed evenly between gaps and forest $\left(\chi^{2}=0.66, \mathrm{df}=1, \mathrm{p}=0.41,62\right.$ captures in gaps and 56 in forest) and represented $17.8 \%$ of the total captures (Figure 4). Overall, $56.4 \%$ of the frugivores captured in gaps were Pipra fasciicauda, while $25 \%$ of the frugivores captured in forest were $M$. oleagineus. The distribution of insectivores was also similar between gaps and forest $\left(\chi^{2}=0.58, \mathrm{df}=1\right.$, $\mathrm{p}=0.44,256$ captures in gaps and 240 in forest). This guild was represented by the largest number of species (74), and contributed $70.2 \%$ of the captures in the gaps and $71.8 \%$ in the forest (Figure 4). The most abundant insectivores were Myrmotherula axillaris (7.5\% of total insectivores captured), Isleria hauxwelli (6.2\%), and Dendrocincla merula (6\%). Sciaphylax hemimelaena and Thamnomanes schistogynus were captured more in gaps than forest (Table 1), contributing $4.4 \%$ and $1.2 \%$, respectively, of the insectivores captured. Omnivores (5.4\% of the captures) were represented by seven species, and had a similar distribution in gaps and forest $\left(\chi^{2}=1.68, \mathrm{df}=1, \mathrm{p}=0.19,11\right.$ captures in gaps and 18 in forest). Ramphocelus carbo contributed $38 \%$ of the omnivores captured, with $36.4 \%$ of the individuals captured in gaps and $38.9 \%$ in forest. We captured piscivores only in the forest $\left(\chi^{2}=2, \mathrm{df}=1, \mathrm{p}=0.15, \mathrm{~N}=2\right)$, two typical forest-dwelling species of the family Alcedinidae, Chloroceryle aenea and Chloroceryle inda.

The height $(W=2, \mathrm{p}=0.001)$ and density $(W=108, \mathrm{p}$ $=0.001)$ of the vegetation varied significantly between gaps and forest. We counted 3,218 plants in the gap plots (214.5 \pm 
40.7; $117-284)$ and 2,588 in the forest plots $(172.5 \pm 46.4$; 68 - 300). The gaps had a high percentage of plants less than $2 \mathrm{~m}$ high, with a much lower percentage of plants over $3 \mathrm{~m}$ in height (Figure 5). Less than 1\% of the plants in the gaps were over $20 \mathrm{~m}$ height. The gaps had a mean size of $238.1 \mathrm{~m}^{2}$ (range: $104-437.4 \mathrm{~m}^{2}$ ).

The pRDA explained $72.5 \%$ of the total variation in bird species abundance in relation to vegetation structure. The bird assemblages were influenced by the vegetation structure $(F=$ $1.75, \mathrm{df}=2, \mathrm{p}=0.001$; adjusted $\left.R^{2}=0.112\right)$. The first $\mathrm{pRDA}$ axis indicated a negative correlation $(-81.7 \%)$ of the variation in total abundance with the height of the vegetation and also indicated a negative correlation (-55.7\%) between vegetation density and the occurrence of some bird species. The second axis indicated that $43.5 \%$ of this variation is explained by the density of the vegetation.

We recorded 19 plants bearing flowers or fruit, representing 13 genera and 12 botanical families (Supplementary Material, Table S2). Abundance $(r=0.06, \mathrm{p}=0.02)$ and richness $(r=$ $0.49, \mathrm{p}=0.05$ ) of frugivore birds and fruit supply in the gaps showed a moderate positive relationship. However, we found no relationship between the number of flowering plants and the abundance $(r=-0.3, \mathrm{p}=0.25)$ and richness $(r=-0.2, \mathrm{p}$ $=0.31)$ of nectarivores.

The two gap-specialist birds were recorded in the forest understory (100\%), and the only forest specialist in the subcanopy (Table 1). Species associated with gaps were recorded in almost all strata (Table 1), primarily in the understory $(71.4 \%)$ and sub-canopy $(57.1 \%)$. Forest-associated species were recorded primarily in the understory (75\%), and subcanopy and forest floor both $37.5 \%$.

Two species that we classified as gap-associated were recorded primarily in the forest sub-canopy: Sittasomus griseicapillus and T. schistogynus. Three (37.5\%) of the eight species associated with the forest also were recorded

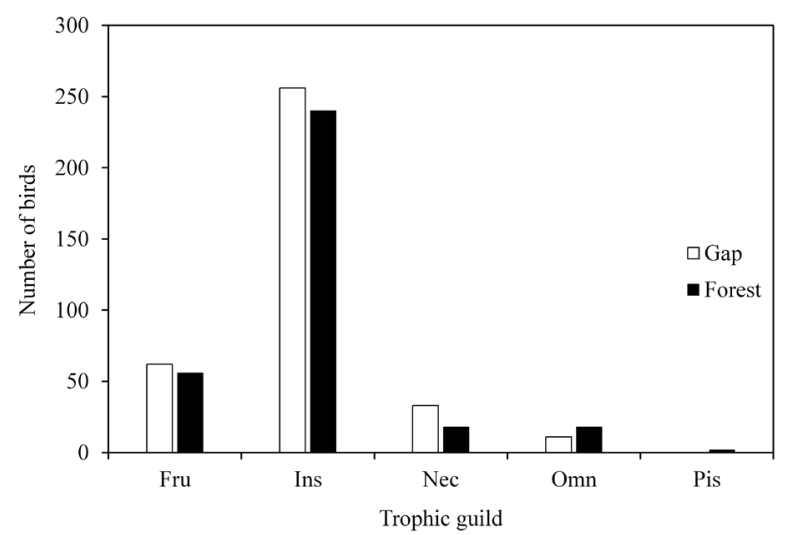

Figure 4. Overall abundance of bird individuals of each trophic guild captured in treefall gap and forest sites in the Humaitá Forest Reserve, southwestern Brazilian Amazonia. Fru = Frugivore; Ins = Insectivore; $\mathrm{Nec}=$ Nectarivore; $\mathrm{Omn}=$ Omnivore; Pis = Piscivore. preferentially in the sub-canopy: Dendrocincla fuliginosa, Glyphorhynchus spirurus, and I. hauxwelli.

\section{DISCUSSION}

\section{Species richness and composition, and bird abundance}

Bird species richness did not vary significantly between gap and forest because most species were captured in the two types of habitat, as recorded in forests of Puerto Rico and Costa Rica (Wunderle et al. 1987; Levey 1988). Thus we could not confirm our assumption that bird assemblages in gaps and forest were different, as reported in Panama and Malaysia (Schemske and Brokaw 1981; Rosely et al. 2007). In the HFR, the availability of food resources in gaps was probably similar to that of the forest, contributing to the similarity in the bird assemblages, in contrast with the pattern suggested by Blake and Hoppes (1986) and Martin and Karr (1986).

\section{Habitat preferences}

We identified species specialized in the exploitation of either treefall gaps or continuous forest and others that were associated with both environments, i.e., species that have some degree of affinity with one habitat, but are not dependent on this environment in the way specialists are. This indicates that a minimal degree of differentiation exists between gap and forest bird assemblages. However, as the gaps found within a given forest will typically present different stages of maturation (Brokaw 1985), we would expect to find an overlap between the bird assemblages in gaps and forest. We suggest that few

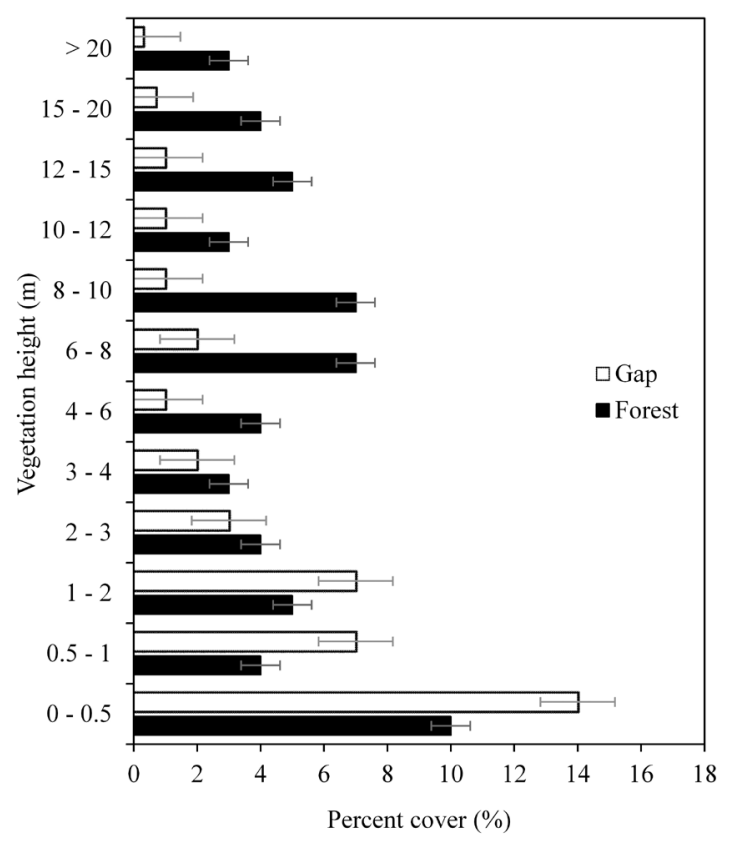

Figure 5. Vegetation height profiles of the 15 gap and 15 forest sites sampled in the Humaitá Forest Reserve, southwestern Brazilian Amazonia. The bars indicate the mean \pm standard error of the percentage cover in each height class. 
forest species have specific adaptations for the exploitation of gap environments at an early stage of regeneration. This would account for the fact that we recorded only two species that were associated strongly with the treefall gaps in the HFR.

In the HFR, we captured only a few individuals of Arremon taciturnus and Cyanocompsa rothschildii, which are associated clearly with Amazonian treefall gaps (Schulenberg et al. 2010). It seems likely that these species may have a preference for larger gaps than those found in the HFR, or occur locally at very low densities. Overall, most species classified as specialists in both habitats in the HFR preferred gap environments, as found in other tropical forests (Schemske and Brokaw 1981; Wunderle et al. 2005). The HFR and El Verde in Puerto Rico had relatively few species associated with gaps. In some tropical forests, species richness and total captures are much higher in gaps than in forest (Levey 1988; Wunderle et al. 2005).

\section{Habitat specialist birds}

We captured individuals of Thamnomanes ardesiacus only in the forest, probably because this species inhabits primarily the understory of terra firme forest (Zimmer and Isler 2003) and, in the HFR, it seems likely that it avoids gaps. Hypocnemis peruviana was associated with gaps in the HFR, a behavior well documented in the Peruvian Amazon (Schulenberg et al. 2010) and also observed for Hypocnemis cantator (currently Spix's Warbling-antbird Hypocnemis striata, Isler et al. 2007) in the Tapajós National Forest (Wunderle et al. 2005). By contrast, Oryzoborus angolensis normally inhabits open areas, natural grassland beyond the forest edge, and secondary forest (Rising and Jaramillo 2011). It is a gap specialist in the HFR. Gaps in the early stages of regeneration offer a range of resources (such as seeds) capable of maintaining this species within the forest, as is the case with its congeners Sporophila aurita (S. corvina) in Costa Rica (Levey 1988) and Sporophila lineola in Brazil (Banks-Leite and Cintra 2008), both known to colonize continuous forest by exploiting gaps efficiently.

\section{Bird movement between gaps and forest}

We showed the actual use of gaps by birds which were recaptured in different gaps in the HFR. This reveals that the birds are moving systematically to these environments to forage, rather than just ranging randomly. The movements of Pipra fasciicauda and Lepidothrix coronata between gaps indicate that they play an important role in dispersing seeds from the forest to gaps and also between gaps (Murray 1988; Snow 1981; Loiselle and Blake 1990; Marini 1992; Piratelli and Mello 2001; Oliveira and Dario 2018).

We observed that Sciaphylax hemimelaena and Xenops minutus, which are common in secondary growth (Laurance et al. 2004), frequently forage in forest edges or gaps in the HFR. Sciaphylax hemimelaena was observed almost daily in the edges of the study gaps (J.L. personal obs.). Probably edge insectivores, birds that exploit gaps, and some frugivores move within the forest via these environments (Laurance $e t$ al. 2004). This behavior appears to be advantageous for many bird species, especially where the forest has undergone significant fragmentation (Lees and Peres 2009). Our results indicate that these movements do occur, and that this pattern may be frequent among all species associated with gaps in the HFR.

\section{Distribution of trophic guilds}

The number of plants flowering and fruiting in gaps was low in the HFR throughout the study period. We observed the nectarivores Amazila lactea, Chlorostilbon mellisugus and Phaethornis ruber foraging constantly within the gaps (J.L. personal obs.), but they were rarely captured. This indicates that, while these species were present in the gaps, our capture method may have been inadequate for the effective sampling of the members of this guild. The low capture rates of frugivores and nectarivores were likely related to the relative scarcity of food resources in the gaps during the study period (Gentry and Emmons 1987), which coincided with the dry season in the study region, which lasts from May to October (Duarte 2007). The same pattern was recorded in Puerto Rico and central Amazonia (Wunderle et al. 1987; Henriques et al. 2003). Despite the low capture rates, the positive correlation we observed between fruit availability and frugivore abundance corroborates the hypothesis that resource availability attracts these birds to the gaps (Willson et al. 1982; Blake and Hoppes 1986; Gomes et al. 2011).

In the HFR, P. fasciicauda was the most abundant frugivore, and was the species most captured in gaps, especially at the sites with a higher concentration of fruiting plants of the families Rubiaceae and Olacaceae. Fruits of Siparuna, Heisteria, Cissus, Psychotria, and Costus are components of the diet of many Neotropical frugivorous birds (Snow 1981), and gaps function as a "key habitat" for the maintenance of populations of frugivorous birds during periods of fruit shortage (Levey 1990). Manakins specialize in eating small fruit (Snow 1981), in particular those of Melastomataceae and Rubiaceae (Piratelli and Mello 2001). Melastomataceae are pioneer species (Mentz and Oliveira 2004) that grow and fruit quickly, taking advantage of the greater input of sunlight in gaps in the forest (Uhl et al. 1988; Brokaw 1985). This may explain why $P$. fasciicauda was the most abundant frugivore in gaps in the HFR.

One gap specialist in the HFR was an insectivore. The high species richness and the abundance of individuals in comparison with other trophic guilds (Wunderle et al. 2005; Neto et al. 2017) corroborate the hypothesis that high concentrations of seedlings and young leaves in early regrowth likely attracts many invertebrates to the gaps (Richards and Coley 2007). Insectivores may be less sensitive to the marked microclimate variation between gap and forest (Wunderle et al. 2006). The even distribution of insectivores in gaps and forest in the HFR is can be related to the active foraging behavior 
of these birds, which move constantly through the forest in search of prey, often in mixed-species flocks dominated by insectivores (Munn and Terborgh 1979), which are common in the HFR (Pedroza et al. 2020), in both gaps and forest (J.L. personal obs.). For example, Thamnomanes schistogynus brings together a number of other species that form high-density, mixed-species flocks that forage together (Munn 1985). This accounts for the capture of a large number of insectivores in the gaps when T. schistogynus was present.

\section{Influence of vegetation structure and forest strata}

In the HFR, species influenced by the vegetation structure of the gaps used the sites with denser vegetation and taller plants, i.e., they prefer gaps at an intermediate or advanced stage of regeneration (Banks-Leite and Cintra 2008). In this stage, the vegetation of gaps generally is relatively dense, offering more substrates for potential food resources such as invertebrates (Didham et al. 1996). The greater height of the vegetation in these gaps also creates different strata that are exploited by a greater variety of bird species, especially insectivores (Felton et al. 2008). Advanced regrowth in gaps thus allows some bird species that normally occupy the highest forest strata to exploit this newly-formed environment. Surprisingly, most of the species that were common in gaps inhabit the sub-canopy and canopy in forest (Schulenberg et al. 2010).

Tachyphonus luctuosus, Veniliornis affinis and Piculus leucolaemus, which all inhabit the forest sub-canopy and canopy, usually were observed in gaps foraging in mixedspecies flocks (J.L. personal obs.). Forest sub-canopy birds are more commonly found in gaps in comparison with canopy birds, given the greater proximity of this stratum to the gap vegetation (Walther 2002). The movement of species from higher forest strata to the understory reflects vertical mobility, as observed in birds in many different rainforests (Schemske and Brokaw 1981; Wunderle et al. 1987; Wunderle et al. 2005). Given this, the occurrence of different species at the level of the mist-nets will vary among forest types (Levey 1988). In the HFR, this reflects a real preference for the gap environment in sub-canopy species, as observed by Schemske and Brokaw (1981) in a tropical forest in Panama, rather than just a tendency to occur in this environment as a random consequence of their movement patterns in the higher strata.

\section{CONCLUSIONS}

The assemblage of understory birds found in natural gaps was similar in species composition and richness to that of the adjacent forest in southwestern Brazilian Amazonia. Yet we identified species that specialize in the use of natural gaps, and others that are closely associated with these environments, but are not dependent on them. Natural gaps are exploited by birds from different strata of the forest, ranging from the ground to the sub-canopy and canopy. The different stages of gap maturation attract an ample diversity of birds that are fundamental to the regeneration and restoration of the forest environment. We suggest that the association of birds with natural forest gaps establishes a link that likely ensures pollination, seed dispersal, and pest control, and guarantees the heterogeneity and resilience of the forest environment following local impacts.

\section{AKNOWLEDGMENTS}

To Coordenação de Aperfeiçoamento de Pessoal de Nível Superior (CAPES) for the scholarships that were essential for financing the expeditions. To Universidade Federal do Acre (UFAC) through its Graduate Program in Ecology and Management of Natural Resources (MECO), for permission and logistical support during the fieldwork in the HFR. To Jhonnatan Machado, for support in the field, which guaranteed access to the gaps. To the team of the UFAC Ornithology Laboratory, for their help in the laboratory and fieldwork in the HFR. To Salatiel Clemente, for help with the statistical analyses. To Marcos Silveira (LABEV) and Evandro Ferreira (INPA), for the identification of the plant specimens. To the reviewers, for important suggestions and criticism that improved an earlier version of this manuscript.

\section{REFERENCES}

Acre. 2010. Zoneamento ecológico-econômico do Acre fase II. Secretaria Estadual do Meio Ambiente, Rio Branco, 152p.

Alvares, C.A.; Stape, J.L.; Sentelhas, P.C.; Gonçalves, J.L.M.; Sparovek, G. 2013. Köppen's climate classification map for Brazil. Meteorologische Zeitschrift, 22: 711-728.

Alvarez, J.; Willig, M.R. 1993. Effects of treefall gaps on the density of land snails in the Luquillo experimental forest of Puerto Rico. Biotropica, 25: 100-110.

Anderson, M.J. 2001. A new method for non-parametric multivariate analysis of variance. Austral Ecology, 26: 32-46.

Baker, T.R.; Díaz, D.M.V.; Moscoso, V.C.; Navarro, G.; Monteagudo, A.; Pinto, R.; et al. 2016. Consistent, small effects of treefall disturbances on the composition and diversity of four Amazonian forests. Journal of Ecology, 104: 497-506.

Banks-Leite, C.; Cintra, R. 2008. The heterogeneity of amazonian treefall gaps and bird community composition. Ecotropica, 14: $1-13$.

Beck, H.; Gaines, M.S.; Hines, J.E.; Nichols, J.D. 2004. Comparative dynamics of small mammal populations in treefall gaps and surrounding understorey within Amazonian rainforest. Oikos, 106: 27-38.

Blake, J.G.; Hoppes, W.G. 1986. Influence of resource abundance on use of tree-fall gaps by birds in an isolated woodlot. Auk, 103: 328-340.

Brokaw, N.V.L. 1982. The definition of treefall gap and its effect on measures of forest dynamics. Biotropica, 14: 158-160.

Brokaw, N.V.L. 1985. Gap-phase regeneration in a tropical forest. Ecology, 66: 682-687. 
Busing, R.T.; Brokaw, N. 2002. Tree species diversity in temperate and tropical forest gaps: the role of lottery recruitment. Folia Geobotanica, 37: 33-43.

Cáceres M.; Legendre P. 2009. Associations between species and groups of sites: Indices and statistical inference. Ecology, 90: 3566-3574.

Crome, F.H.J.; Richards, G.C. 1988. Bats and gaps: microchiropteran community structure in a Queensland rain forest. Ecology, 69: 1960-1969.

Daly, D.C.; Silveira, M. 2008. Primeiro Catálago da Flora do Acre, Brasil/First Catalogue of the Flora of Acre, Brazil. Edufac, Rio Branco, 555p.

Didham, R.K.; Ghazoul, J.; Stork, N.E.; Davis, A. 1996. Insects in fragmented forests: A functional approach. Trends in Ecology \& Evolution, 11: 255-260.

Duarte, A.F. 2006. Aspectos da climatologia do Acre, Brasil, com base no intervalo 1971 -2000. Revista Brasileira de Meteorologia, 21: 308-317.

Duarte, A.F. 2007. Hidrometria no Acre: Clima, Mediçôes e Informaçōes Meteorológicas. Edufac, Rio Branco, 121p.

ESRI. 2015. ArcGIS Desktop. Redlands, CA: Environmental Systems Research Institute.

Felton, A.; Wood, J.T.; Felton, A.M.; Hennessey, B.A.; Lindenmayer, D.B. 2008. A comparison of bird communities in the anthropogenic and natural-tree fall gaps of a reduced-impact logged subtropical forest in Bolivia. Bird Conservation International, 18: 129-143.

Freitas, W.K.; Magalhães, L.M.S. 2012. Métodos e parâmetros para estudo da vegetação com ênfase no estrato arbóreo. Floresta e Ambiente, 19: 520-540.

Garwood, N.C.; Janos, D.P.; Brokaw, N. 1979. Earthquake-caused landslides: a major disturbance to tropical forests. Science, 205: 997-999.

Gentry, A.H.; Emmons, L.H. 1987. Geographical variation in fertility and composition of the understory of Neotropical forests. Biotropica, 19: 216-227.

Gill, F.; Donsker D. (Ed.). 2019. IOC World Bird Names (Version 9. 1). doi 10.14344/IOC.ML.9.1. (http://www.worldbirdnames.org/).

Gomes, V.S.M.; Tamashiro, J.Y.; Silva, W.R. 2011. Seed inflow to a forest patch promoted by understory frugivorous birds. Biota Neotropica, 11: 95-102.

Guilherme, E. 2001. Comunidade de aves do Campus e Parque Zoobotânico da Universidade Federal do Acre, Brasil. Tangara, 1: 57-73.

Guilherme, E. 2012. Birds of the brazilian state of Acre: diversity, zoogeography, and conservation. Revista Brasileira de Ornitologia, 20: 393-442.

Guilherme, E. 2016. Aves do Acre. Edufac, Rio Branco, 900p.

Henriques, L.M.P.; Wunderle Jr., J.M.; Willig, M.R. 2003. Birds of the Tapajos National Forest, brazilian Amazon: A preliminary assessment. Ornitología Neotropical, 14: 307-338.

Hubbell, S.P.; Foster, R.B.; O’Brien, S.T.; Harms, K.E.; Condit, R.; Wechsler, B.; Wright, S.J.; Loo de Lao, S. 1999. Lightgap disturbances, recruitment limitation, and tree diversity in a Neotropical forest. Science, 283: 554-557.

IBGE. 2012. Manual Técnico da Vegetação Brasileira. Instituto Brasileiro de Geografia e Estatística, Rio de Janeiro, 275p.
Isler, M.L.; Isler, P.R.; Whitney, B.M. 2007. Species limits in antbirds (Thamnophilidae): The warbling antbird (Hypocnemis cantator) complex. Auk, 124: 11-28.

Laurance, S.G.W.; Stouffer, P.C.; Laurance, W.F. 2004. Effects of road clearings on movement patterns of understory rainforest birds in central Amazonia. Conservation Biology, 18: 1099-1109.

Lees, A.C.; Peres, C.A. 2009. Gap-crossing movements predict species occupancy in Amazonian forest fragments. Oikos, 118: 280-290.

Legendre, P.; Lengendre, L. 1998. Numerical Ecology. Elsevier, Amsterdam, 853p.

Levey, D.J. 1988. Tropical wet forest treefall gaps and distribution of understory birds and plants. Ecology, 69: 1076-1089.

Levey, D.J. 1990. Habitat-dependent fruiting behavior of an understory tree, Miconia centrodesma, and tropical treefall gaps as keystone habitat for frugivores in Costa Rica. Journal of Tropical Ecology, 6: 409-420.

Lima, R.A.F. 2005. Estrutura e regeneração de clareiras em Florestas Pluviais Tropicais. Revista Brasileira de Botânica, 28: 651-670.

Loiselle, B.; Blake, J. 1990. Diets of understory fruit-eating birds in Costa Rica: seasonality and resource abundance. Studies in Avian Biology, 13: 91-103.

Maranho, A.S.; Salimon, C.I. 2015. Maranthaceae overabundance decreases richness and abundance of regenerating woody plants in natural gaps. Neotropical Biology and Conservation, 10: 53-62.

Marini, M.A. 1992. Foraging behavior and diet of the Helmeted Manakin. Condor, 94: 151-158.

Martin, T.E.; Karr J.R. 1986. Patch utilization by migrating birds: resource oriented? Ornis Scandinavica, 17: 165-174.

Medeiros, H.; Obermüller, F.A.; Daly, D.C.; Silveira, M.; Castro, W.; Forzza, R.C. 2014. Botanical advances in Southwestern Amazonia: The flora of Acre (Brazil) five years after the first Catalogue. Phytotaxa, 177: 101-117.

Mentz, L.A.; Oliveira, P.L. 2004. Solanum (Solanaceae) na região Sul do Brasil. Pesquisas Botânica, 54: 1-357.

Mestre, L.A.M.; Thom, G.; Cochrane, M.A.; Barlow, J. 2010. The birds of Reserva Extrativista Chico Mendes, South Acre, Brazil. Boletim do Museu Paraense Emílio Goeldi, Ciências Naturais, 5: 311-333.

Munn, C.A. 1985. Permanent canopy and understory flocks in Amazonia: species composition and population density. Ornithological Monographs, 36: 683-712.

Munn, C.A.; Terborgh, J.W. 1979. Multi-species territoriality in Neotropical foraging flocks. Condor, 81: 338-347.

Murray, K.G. 1988. Avian seed dispersal of three Neotropical gapdependent plants. Ecological Monographs, 58: 271-298.

Neto, P.A.F.P.; Marques, B.H.; Fonseca, R.C.B. 2017. Distribution of birds in natural gaps of different sizes in a seasonal semideciduous forest in São Paulo state, Brazil. Atualidades Ornitológicas, 195: 49-58.

Oksanen, J.; Blanchet, F.G.; Friendly, M.; Kindt, R.; Legendre, P.; McGlinn, D.; et al. 2018. Vegan: Community Ecology Package. $\mathrm{R}$ package version 2.5-3.

Oliveira, N.L.S; Dario, F.R. 2018. Diversity of birds and their ecological interactions in the Mura Indigenous Territory, Brazilian Amazon rainforest. World News of Natural Science, 20: 85-102. 
Pardonnet, S.; Beck, H.; Milberg, P.; Bergman, K-O. 2013. Effect of tree-fall gaps on fruit-feeding nymphalid butterfly assemblages in a Peruvian rain forest. Biotropica, 45: 612-619.

Pedroza, D.; Melo, T.N.; Machado, T.L.S.; Guimarães, D.P.; Lima, J.M.; Guilherme, E. 2020. Birds of Humaitá Forest Reserve, Acre, Brazil: an important forest fragment in south-western Amazonia. Bulletin of the British Ornithologists' Club, 14: 58-79.

Peres, M.C.L.; Benati, K.R.; Dias, M.A.; Melo, T.S.; Sena, T.U. 2014. Diversidade de aracnídeos em clareiras naturais e interior de floresta atlântica no Parque Metropolitano de Pituaçu, Bahia, Brasil. Revista Biociências, 20: 39-49.

Piratelli, A.; Mello, M.C. 2001. Biologia do uirapuru-laranja (Pipra fasciicauda) no estado de Mato Grosso do Sul, Brasil. Tangara, 1: 157-167.

Rasmussen, D.T.; Rehg, J.A.; Guilherme, E. 2005. Avifauna da Fazenda Experimental Catuaba: uma pequena reserva florestal no leste do Estado do Acre, Brasil. In: Drumond P.M. (Org.). Fauna do Acre. Edufac, Rio Branco, p.173-198.

R Development Core Team. 2018. R: A language and environment for statistical computing. R Foundation for Statistical Computing, Vienna.

Richards, L.A.; Coley, P.D. 2007. Seasonal and habitat differences affect the impact of food and predation on herbivores: a comparison between gaps and understory of a tropical forest. Oikos, 116: 31-40.

Rising, J.D.; Jaramillo, A. 2011. Chestnut-bellied Seed-finch (Sporophila angolensis). In: del Hoyo, J.; Elliott, A.; Sargatal, J.; Christie, D.A.; de Juana, E. (Ed.). Handbook of the Birds of the World. Lynx Edicions, Barcelona, 663p.

Rosely, N.F.N.; Sah, S.A.M.; Mansor, M. 2007. Avian distribution and diversity in forest gap and closed canopy areas of lowland tropical forest. Jurnal Biosains, 18: 57-75.

Scharenbroch, B.C.; Bockheim, J.G. 2008. Gaps and soil C dynamics in old growth northern hardwood-hemlock forests. Ecosystems, 11: 426-441.

Schemske, D.W.; Brokaw, N. 1981. Treefalls and the distribution of understory birds in a tropical forest. Ecology, 62: 938-945.

Schnitzer, S.A.; Carson, W.P. 2010. Lianas suppress tree regeneration and diversity in treefall gaps. Ecology Letters, 13: 849-857.

Schulenberg, T.S.; Stotz, D.F.; Lane, D.F.; O’Neill, J.P.; Parker III, T.A. 2010. Birds of Peru. Revised and updated edition, Princeton University Press, New Jersey, 664p.

Scheiner, S.M.; Cox, S.B.; Willig, M.; Mittelbach, G.G.; Osenberg, C.; Kaspari, M. 2000. Species richness, species-area curves and Simpson's paradox. Evolutionary Ecology Research, 2: 791-802.

Silva, T.L.; Marques, E.L.; Guilherme, E. 2015. Recuperation of the terra firme forest understory bird fauna eight years after a wildfire in eastern Acre, Brazil. International Journal of Ecology, 2015: 1-13.
Snow, D.W. 1981. Tropical frugivorous birds and their food plants: a world survey. Tropical Ecology, 13: 1-14.

Sokal, R.R.; Rohlf, F.J. 1995. Biometry. W. H. Freeman and Company, New York, 887p.

Sousa, W.P. 1984. The role of disturbance in natural communities. Annual Review of Ecology and Systematics, 15: 353-391.

Strojny, C.J.; Hunter, M.L. 2010. Relative abundance of amphibians in forest canopy gaps of natural origin vs. timber harvest origin Animal Biodiversity and Conservation, 33: 1-13.

Terborgh, J.; Nuñez, N.H.; Loayza, P.A.; Valverde, F.C. 2017. Gaps contribute tree diversity to a tropical floodplain forest. Ecology, 98: 2895-2903.

Thompson, E.H.; Sorenson, E.R. 2000. Wetland, Woodland, Wildland: A Guide to the Natural Communities of Vermont. Queen City Printers Inc, USA, 468p.

Townsend, C.R.; Begon, M.; Harper, J.L. 2010. Fundamentos em Ecologia. Artmed, Porto Alegre, 576p.

Uhl, C.; Clark, K.; Dezzeo, N.; Maquirino, P. 1988. Vegetation dynamics in Amazonian treefall gaps. Ecology, 69: 751-763.

Walther, B.A. 2002. Grounded ground birds and surfing canopy birds: variation of foraging stratum breadth observed in Neotropical forest birds and tested with simulation models using boundary constraints. Auk, 119: 658-675.

Whittaker, R.H.; Levin, S.A. 1977. The role of mosaic phenomena in natural communities. Theoretical Population Biology, 12: 117-139.

Willson, M.F.; Porter, E.A.; Condit, R.S. 1982. Avian frugivore activity in relation to forest light gaps. Caribbean Journal of Science, 18: 1-6.

Wilman, H.; Belmaker, J.; Simpson, J.; Rosa, C.; Rivadeneira, M.M.; Jetz, W. 2014. EltonTraits 1.0: Species-level foraging attributes of the world's birds and mammals. Ecology, 95: 2027-2027.

Wunderle Jr, J.M.; Diaz, A.; Velazquez, I.; Scharron, R. 1987. Forest openings and the distribution of understory birds in a Puerto Rican rainforest. Wilson Bulletin, 99: 22-37.

Wunderle Jr, J.M.; Willig, M.R.; Henriques, L.M.P. 2005. Avian distribution in treefall gaps and understory of terra firme forest in the lowland Amazon. Ibis, 147: 109-129.

Wunderle Jr, J.M.; Henriques, L.M.P.; Willig, M.R. 2006. Shortterm responses of birds to forest gaps and understory: an assessment of reduced-impact logging in a lowland Amazon forest. Biotropica, 38: 235-255.

Zimmer, K.J.; Isler, M.L. 2003. Typical Antbirds (Thamnophilidae). In: del Hoyo, J.; Elliott, A.; Christie, D.A. (Ed.). Handbook of the Birds of the World. Broadbills to Tapaculos. Lynx Edicions, Barcelona, p.448-531.

RECEIVED: 07/06/2020

ACCEPTED: $16 / 10 / 2020$

ASSOCIATE EDITOR: Sérgio H. Borges 
SUPPLEMENTARY MATERIAL (only available in the electronic version)

Lima \& Guilherme. Birds associated with treefall gaps in a lowland forest in southwestern Brazilian Amazonia.

Table S1. Number of birds per species captured per habitat (15 treefall-gap and 15 forest sites) in the Humaitá Forest Reserve, southwestern Brazilian Amazonia. Guild: $\mathrm{F}=$ frugivore, $\mathrm{I}=$ insectivore, $\mathrm{N}=$ nectarivore $\mathrm{O}=$ omnivore, $\mathrm{P}=$ piscivore. Stratum: $\mathrm{T}=$ terrestrial, $\mathrm{U}=$ understory, $\mathrm{Sc}=$ sub-canopy, $\mathrm{C}=$ canopy, $\mathrm{Sf}=$ secondary forest, $\mathrm{Fe}=$ forest edge, $\mathrm{Tf}=$ treefall. ${ }^{*}$ Treefall gap specialist in the HFR. ${ }^{+}$Forest specialist in the HFR. Nomenclature and taxonomic orders follow Gill and Donsker (2019). Guild classification follows Wilman et al. (2014). Foraging strata follow Henriques et al. (2003) and Schulenberg et al. (2010).

\begin{tabular}{lcccc}
\hline Family/Species & Gap & Forest & Guild & Stratum \\
\hline $\begin{array}{l}\text { Columbidae } \\
\text { Leptotila rufaxilla }\end{array}$ & 1 & 1 & $\mathrm{~F}$ & $\mathrm{~T}, \mathrm{Fe}$ \\
$\begin{array}{l}\text { Geotrygon montana } \\
\text { Cuculidae }\end{array}$ & 1 & 4 & $\mathrm{O}$ & $\mathrm{T}$ \\
$\begin{array}{l}\text { Coccycua minuta } \\
\text { Trochilidae }\end{array}$ & 2 & 0 & $\mathrm{I}$ & $\mathrm{Sc}, \mathrm{Fe}$ \\
Glaucis hirsutus & & & & \\
Threnetes leucurus & 9 & 2 & $\mathrm{~N}$ & $\mathrm{~S}, \mathrm{Fe}$ \\
Phaethornis hispidus & 0 & 1 & $\mathrm{~N}$ & $\mathrm{U}, \mathrm{Fe}, \mathrm{Sf}$ \\
Phaethornis bourcieri & 5 & 7 & $\mathrm{~N}$ & $\mathrm{U}, \mathrm{SC}$ \\
$\begin{array}{l}\text { Phaethornis ruber } \\
\text { Campylopterus largipennis }\end{array}$ & 4 & 1 & $\mathrm{~N}$ & $\mathrm{U}$ \\
Chlorostilbon mellisugus & 3 & 2 & $\mathrm{~N}$ & $\mathrm{U}$ \\
Thalurania furcata & 0 & 1 & $\mathrm{~N}$ & $\mathrm{C}, \mathrm{Fe}$ \\
Hylocharis cyanus & 1 & 0 & $\mathrm{~N}$ & $\mathrm{Sc}, \mathrm{Fe}, \mathrm{Sf}$ \\
Amazilia lactea & 8 & 1 & $\mathrm{~N}$ & $\mathrm{C}, \mathrm{Tf}$ \\
\hline Alcedinidae & 1 & 3 & $\mathrm{~N}$ & $\mathrm{U}, \mathrm{SC}, \mathrm{C}$ \\
& 2 & 0 & $\mathrm{~N}$ & $\mathrm{Sc}, \mathrm{Fe}$ \\
\hline
\end{tabular}

\begin{tabular}{lcccc}
\hline $\begin{array}{l}\text { Alcedinidae } \\
\text { Chloroceryle aenea } \\
\text { Chloroceryle inda }\end{array}$ & 0 & 1 & $\mathrm{P}$ & $\mathrm{Fe}$ \\
\hline $\begin{array}{l}\text { Momotidae } \\
\text { Momotus momota }\end{array}$ & 0 & 1 & $\mathrm{P}$ & $\mathrm{Fe}$ \\
\hline Galbulidae & 0 & 2 & $\mathrm{O}$ & $\mathrm{SC}$ \\
$\begin{array}{l}\text { Galbula cyanicollis } \\
\text { Galbula cyanescens }\end{array}$ & 2 & 1 & $\mathrm{I}$ & $\mathrm{SC}$ \\
\hline Bucconidae & 1 & 0 & $\mathrm{I}$ & $\mathrm{Tf}, \mathrm{Fe}$ \\
Nonnula sclateri & & & & \\
Nonnula ruficapilla & 2 & 0 & $\mathrm{I}$ & $\mathrm{T}, \mathrm{U}$ \\
Monasa nigrifrons & 0 & 1 & $\mathrm{I}$ & $\mathrm{Fe}$ \\
Monasa morphoeus & 1 & 0 & $\mathrm{I}$ & $\mathrm{SC}, \mathrm{C}$ \\
\hline Ramphastidae & 1 & 0 & $\mathrm{I}$ & $\mathrm{SC}$ \\
$\begin{array}{l}\text { Pteroglossus inscriptus } \\
\text { Pteroglossus mariae }\end{array}$ & 1 & 0 & $\mathrm{~F}$ & $\mathrm{C}$ \\
Pteroglossus beauharnaesii & 1 & 0 & $\mathrm{~F}$ & $\mathrm{C}$ \\
\hline Picidae & 0 & 1 & $\mathrm{~F}$ & $\mathrm{C}$ \\
\hline
\end{tabular}

\begin{tabular}{lcccc}
\hline Picidae & 2 & 0 & I & Fe, Sf \\
Veniliornis passerinus & 2 & 2 & I & Sc, U \\
Veniliornis affinis & 1 & 0 & I & $\mathrm{C}$ \\
Piculus leucolaemus & 1 & 0 & $\mathrm{I}$ & $\mathrm{C}, \mathrm{SC}$ \\
$\begin{array}{l}\text { Campephilus rubricollis } \\
\text { Furnariidae }\end{array}$ & 1 & & & \\
Sclerurus mexicanus & 5 & 6 & $\mathrm{I}$ & $\mathrm{T}$ \\
Sclerurus caudacutus & 8 & 4 & $\mathrm{~T}$ & $\mathrm{U}, \mathrm{SC}$ \\
Sittasomus griseicapillus & 10 & 20 & $\mathrm{I}$ & $\mathrm{U}$ \\
Dendrocincla merula & & & &
\end{tabular}

Table S1. Continued

\begin{tabular}{lcccc}
\hline Family/Species & Gap & Forest & Guild & Stratum \\
\hline Dendrocincla fuliginosa & 5 & 11 & I & S, Sc \\
Glyphorynchus spirurus & 3 & 9 & I & U, Sc \\
Dendrocolaptes certhia & 4 & 1 & I & Sc \\
Dendrocolaptes picumnus & 1 & 1 & I & Sc \\
Xiphorhynchus elegans & 1 & 2 & I & U \\
Xiphorhynchus guttatus & 1 & 1 & I & $\mathrm{C}, \mathrm{SC}$ \\
Campylorhamphus trochilirostris & 0 & 3 & I & $\mathrm{Sc}, \mathrm{U}$ \\
Xenops minutus & 6 & 3 & I & $\mathrm{U}, \mathrm{SC}$ \\
Philydor erythrocercum & 0 & 1 & $\mathrm{I}$ & $\mathrm{U}, \mathrm{C}$ \\
Automolus rufipileatus & 0 & 1 & $\mathrm{I}$ & $\mathrm{U}$ \\
Automolus melanopezus & 1 & 0 & $\mathrm{I}$ & $\mathrm{U}$ \\
Automolus ochrolaemus & 11 & 11 & $\mathrm{I}$ & $\mathrm{U}$ \\
Automolus subulatus & 1 & 0 & $\mathrm{I}$ & $\mathrm{SC}$ \\
Synallaxis rutilans & 2 & 0 & $\mathrm{I}$ & $\mathrm{U}$ \\
\hline
\end{tabular}

\section{Thamnophilidae}

Epinecrophylla leucophthalma

Epinecrophylla ornata

Myrmotherula axillaris

Myrmotherula longipennis

Dichrozona cincta

Isleria hauxwelli

Thamnomanes ardesiacus ${ }^{\dagger}$

Thamnomanes schistogynus

Thamnophilus aethiops

Thamnophilus schistaceus

Oneillornis salvini

Rhegmatorhina melanosticta

Phlegopsis nigromaculata

Willisornis poecilinotus

Hypocnemis peruviana*

Hypocnemis subflava

Sciaphylax hemimelaena

Myrmelastes hyperythrus

Myrmelastes humaythae

Myrmoborus myotherinus

\begin{tabular}{cccc}
1 & 3 & $:$ & U, Sc \\
2 & 3 & $:$ & $\mathrm{Sc}, \mathrm{U}$ \\
26 & 11 & $:$ & $\mathrm{U}, \mathrm{Sf}, \mathrm{Tf}, \mathrm{Fe}$ \\
3 & 0 & $:$ & $\mathrm{U}$ \\
0 & 1 & $:$ & $\mathrm{T}$ \\
15 & 16 & $:$ & $\mathrm{U}, \mathrm{Sc}$ \\
0 & 7 & $:$ & $\mathrm{Sc}$ \\
10 & 4 & $\mathrm{Sc}$ \\
11 & 11 & $:$ & $\mathrm{U}$ \\
4 & 1 & $:$ & $\mathrm{U}$ \\
9 & 16 & $:$ & $\mathrm{T}, \mathrm{U}$ \\
0 & 1 & $:$ & $\mathrm{U}$ \\
6 & 12 & $:$ & $\mathrm{U}, \mathrm{T}$ \\
7 & 15 & $:$ & $\mathrm{U}$ \\
14 & 1 & $:$ & $\mathrm{U}, \mathrm{Fe}, \mathrm{Tf}, \mathrm{Sf}$ \\
2 & 0 & $:$ & $\mathrm{U}$ \\
16 & 7 & $:$ & $\mathrm{U}, \mathrm{Sf}, \mathrm{Fe}$ \\
0 & 2 & $:$ & $\mathrm{U}, \mathrm{Fe}$ \\
1 & 0 & $:$ & $\mathrm{U}, \mathrm{Sf}, \mathrm{Fe}$ \\
5 & 7 & $:$ & $\mathrm{U}$ \\
\hline
\end{tabular}

\section{Formicariidae}

Formicarius colma

\section{Tyrannidae}

Corythopis torquatus

Mionectes oleagineus

Leptopogon amaurocephalus

Hemitriccus flammulatus

Myiornis ecaudatus

Lophotriccus eulophotes

Poecilotriccus latirostris

Cnipodectes superrufus

Rhynchocyclus olivaceus

Platyrinchus coronatus

Platyrinchus platyrhynchos

T

\begin{tabular}{|c|c|c|c|}
\hline 3 & 2 & 1 & $U, T$ \\
\hline 6 & 14 & $\mathrm{~F}$ & U \\
\hline 6 & 6 & I & U, SC \\
\hline 4 & 2 & I & u \\
\hline 1 & 0 & I & $\mathrm{Sc}_{\mathrm{C}} \mathrm{Fe}$ \\
\hline 6 & 3 & I & $\mathrm{Sc}, \mathrm{Fe}, \mathrm{St}$ \\
\hline 1 & 0 & I & $\mathrm{Sf}, \mathrm{Fe}$ \\
\hline 0 & 1 & I & $\mathrm{SC}_{\mathrm{C}} \mathrm{U}$ \\
\hline 0 & 1 & I & Sc \\
\hline 1 & 1 & I & U \\
\hline 0 & 2 & I & U \\
\hline
\end{tabular}


Table S1. Continued.

\begin{tabular}{lcccc}
\hline Family/Species & Gap & Forest & Guild & Stratum \\
\hline Lathrotriccus euleri & 2 & 1 & $\mathrm{I}$ & $\mathrm{U}$ \\
Cnemotriccus fuscatus & 0 & 1 & $\mathrm{I}$ & $\mathrm{S}, \mathrm{Fe}, \mathrm{Sf}$ \\
Rhytipterna simplex & 2 & 1 & $\mathrm{I}$ & $\mathrm{SC}$ \\
Ramphotrigon megacephalum & 3 & 3 & $\mathrm{I}$ & $\mathrm{U}, \mathrm{Sc}$ \\
Attila spadiceus & 2 & 1 & $\mathrm{O}$ & $\mathrm{C}, \mathrm{Sc}$ \\
\hline
\end{tabular}

\section{Pipridae}

\begin{tabular}{lcccc} 
Lepidothrix coronata & 5 & 4 & F & U, Sc \\
Piprafasciicauda & 35 & 30 & F & U \\
Machaeropterus pyrocephalus & 3 & 0 & F & Sc, U \\
\hline
\end{tabular}

\section{Tityridae}

$\begin{array}{llllc}\text { Onychorhynchus coronatus } & 2 & 4 & \text { I } & \text { U } \\ \text { Terenotriccus erythrurus } & 5 & 6 & \text { I } & \text { Sc, U } \\ \text { Laniocera hypopyrra } & 1 & 2 & \text { I } & \text { SC }\end{array}$

\begin{tabular}{lllll}
\hline Troglodytidae & & & & \\
Pheugopedius genibarbis & 5 & 1 & | & U \\
Cantorchilus leucotis & 0 & 1 & । & U, Fe \\
\hline
\end{tabular}

\begin{tabular}{lllll}
\hline Turdidae & & & & \\
Turdus amaurochalinus & 0 & 1 & $\mathrm{~F}$ & $\mathrm{Fe}, \mathrm{Sf}$ \\
Turdus ignobilis & 0 & 1 & 0 & $\mathrm{Fe}, \mathrm{Sf}$ \\
Turdus hauxwelli & 0 & 2 & 0 & $\mathrm{~T}, \mathrm{Sc}$ \\
\hline Passerellidae
\end{tabular}

\section{Passerellidae}

Arremon taciturnus 4

10

$\mathrm{U}, \mathrm{Fe}$

\section{Cardinalidae}

Habia rubica

\section{Thraupidae}

\begin{tabular}{lcccc} 
Eucometis penicillata & 0 & 1 & $\mathrm{I}$ & $\mathrm{U}, \mathrm{Sc}$ \\
Tachyphonus luctuosus & 2 & 0 & $\mathrm{I}$ & $\mathrm{Sc}, \mathrm{Fe}$ \\
Ramphocelus carbo & 4 & 7 & $\mathrm{O}$ & $\mathrm{Fe}$ \\
Thraupis palmarum & 0 & 2 & $\mathrm{~F}$ & $\mathrm{C}, \mathrm{Fe}$ \\
Saltator grossus & 1 & 0 & $\mathrm{I}$ & $\mathrm{Sc}$ \\
Saltator maximus & 2 & 0 & $\mathrm{I}$ & $\mathrm{SC}$ \\
Oryzoborus angolensis* & 12 & 2 & $\mathrm{G}$ & $\mathrm{T}, \mathrm{U}, \mathrm{Fe}, \mathrm{Tf}$ \\
\hline
\end{tabular}

Table S2. Flowering and/or fruiting plant genera and species recorded in 15 treefall gaps from May 13th to November 19th, 2018, in the Humaitá Forest Reserve, southwestern Brazilian Amazonia. Botanical nomenclature follows Daly and Silveira (2008) and Medeiros et al. (2014).

\begin{tabular}{lcc}
\hline Family & Genus/Species & Status \\
\hline Acanthaceae & Pachystachys spicata (Ruiz and Pav.) Wassh & Flower \\
\hline Arecaceae & Geonoma laxiflora Mart. & Fruit \\
\hline Bignoniaceae & Arrabidaea sp. DC. & Flower \\
\hline Chrysobalanaceae & Hirtella sp. L. & Flower \\
\hline Costaceae & Costus arabicus L. & Flower \\
\hline Euphorbiaceae & Pausandra trianae (Müll.Arg) Baill. & Fruit \\
\hline Siparunaceae & Siparuna guianensis Aubl. & Fruit \\
\hline Myrtaceae & Myrcia sp. DC. & Flower \\
\hline Olacaceae & Heisteria nitida Spruce ex Engl. & Fruit \\
\hline Rubiaceae & Faramea sp. Aubl. & Fruit \\
\hline Rubiaceae & Psychotria sp. L. & Flower \\
Violaceae & Rinorea sp. Aubl. & Fruit \\
Vitaceae & Cissus sp. 1 L. & Flower \\
Vitaceae & Cissus sp. 2 L. & Flower \\
\hline
\end{tabular}

